\title{
Physiological role of epicuticular waxes for plants and their practical significance
}

\author{
Ivaschenko $0 .{ }^{1}$, Ivaschenko $0^{2}$ \\ ${ }^{1}$ Institute of biopower crops and sugar beet of NAAS, Clinichna Str., 25, Kyiv, 03141, Ukraine, ${ }^{2}$ Institute of \\ protection of plants of NAAS, Vasylkivska Str., 33, Kyiv, 03022, Ukraine; e-mail: \\ ${ }^{1}$ O_ivashchenko@ukr.net, ${ }^{2}$ plant_prot@ukr.net
}

The purpose. To specify the features of dynamics of formation of a layer of epicuticular waxes on leaves of weeds of different sorts during their organogenesis under different conditions of vegetation of plants and determination of role of such layer in use of herbicides. Methods. Probes were carried out in laboratories of herbology of IBCSB and IPP of NAAS in 2014-2018. The cultivated area of microplot $-1 \mathrm{~m}^{2}$, registration plot $-0,5 \mathrm{~m}^{2}$. Frequency of experiments -7 -fold. On plots they kept 50 plants of one sort of weeds for $1 \mathrm{~m}^{2}$. All alternatives of experiments were realized both in conditions of open ground and under the polymerous transparent film (sheltered ground) where conditions of vegetation were more stable. The square of leaves for analysis was determined by method of "notchings" (A.A. Nichiporovich). For determination of amount of epicuticular waxes on leaves they used "washing off" method. After sampling leaves of plants for analysis the plot were sprayed with herbicide Betanal expert k.e. (phenmedipham - $91 \mathrm{~g} / \mathrm{l}+$ desmedipham $-71+$ ethofumezat $110 \mathrm{~g} / \mathrm{l}$ ) in rate of application of 1,0 l/hectare and dose of importation of working fluid of $210 \mathrm{l} / \mathrm{h}$ ectare. Results. Analysis proved that on the surface of green seed-lobe of different sorts of weeds used in experiments, epicuticular waxes were almost absent. To the time of formation of 4 leaves at juvenile plants intensity of formation of layer epicuticular waxes increased. Their average amount at plants of white goosefoot was $0,24 \mathrm{~g} / \mathrm{m}^{2}$, or on $50 \%$ more than in the previous records, at plants of asperous jointweed $-0,26 \mathrm{~g} / \mathrm{m}^{2}$, or on $24 \%$ more in comparison to previous indexes, at sprouts of amaranth $-0,31 \mathrm{~g} / \mathrm{m}^{2}$, or on $35 \%$ more than in the phase of 2 leaves. In phases of formation of leaves and accumulation of more powerful layer of epicuticular waxes sprouts of weeds manifested phase resistance to action of herbicide. Conclusions. Epicuticular waxes are essential obstruction in diffusion of acting matters of herbicides in tissue of mesophyll of leaves. The augmentation in 5,6 times of amount of waxes on leaves of plants of asperous jointweed during their development coincided with the level of recession of efficiency of herbicide on $62 \%, r=0,723$. At plants of amaranth at augmentation of accumulation of epicuticular waxes from 0,09 up to $0,72 \mathrm{~g} / \mathrm{m}^{2}$ the level of efficiency of herbicide decreased from 100 to $35 \%, r=0,886$.

Key words: weeds, epicuticular waxes, herbicides, efficiency of action.

$$
\text { https://doi.org/10.31073/agrovisnyk201901-02 }
$$

Epicutecular waxes are complex organic substances that have a lipidic chemical nature. In the process of forming protective systems against adverse environmental effects, the membrane of the epidermis cells (epidermal) is impregnated with a variety of plant waxes - the corn. Epicutilus waxes by nature are a mixture of esters of higher fatty acids and aliphatic alcohols, stearins and terpene alcohols. Such an amorphous layer on the surface substantially enhances the protective functions of the covering tissues of plants. It is bad or not wetted by water, does not pass water vapor and gases. Method. The research was conducted in labs of IBBI and IAR NAAS in the period 2014-2018. Sowing area of a micro area - one meter square. The accounting area is $0.5 \mathrm{~m}^{2}$. Repeat experiments -7-and one-time. On the plot left about $50 \mathrm{pcs} / \mathrm{m}^{2}$ of plants of one type of weed. In parallel, all experimental variants were laid in both open soil and vegetation under a polymeric transparent film (protected soil), where the vegetation conditions of the plants were more stable. The areas selected for the analysis of leaves were determined 
by the method of "broaching" (according to AA Nichiporovich). To determine the number of epicutileous waxes on the leaves, the method of "washing" was used. After sampling sheets for analysis, the sprays were sprayed with herbicide Betanal expert k.e. (for fenemidifes - $91 \mathrm{~g} / \mathrm{I}+$ desmedipham - $71 \mathrm{~g} / \mathrm{I}+$ ethofumezate $110 \mathrm{~g} / \mathrm{l}$.) Normally the consumption is $1.0 \mathrm{I} / \mathrm{ha}$ and the rate of consumption of the working fluid is $210 \mathrm{I} / \mathrm{ha}$. Discussion. The analyzes conducted prove that on the surface of the green cotyledons of different types of weeds that were used in experiments, epicutilus waxes are almost absent. By the time of the formation of 4 leaves in juvenile plants, the intensity of the formation of the layer of epicatetic waxes increased. Their average number was: in Chenopodoum album L. plants $-0.24 \mathrm{~g} / \mathrm{m}^{2}$ or $50 \%$ more than previous records. In Polygonum scabrum L. plants $-0,26 \mathrm{~g} / \mathrm{m}^{2}$ or $24 \%$ more compared with the previous indices, in the Amaranthus retroflexus $L$. $-0,31 \mathrm{~g} / \mathrm{m}^{2}$ or $35 \%$ more than in the phase of 2 leaves. With the growth of the phases of the formation of leaves and the accumulation of a more powerful layer of epicutile waxes, weed stairs showed a phase resistance to the action of the herbicide. Conclusions Epicutilus waxes are a significant obstacle to the diffusion of active substances of herbicides into the tissue of mesophilic leaves. The growth of 5.6 times the number of waxes on the leaves of rough Polygonum scabrum L. plants in the process of their development coincided with a decrease in the level of effectiveness of the herbicide by $62 \%$, the relationship of factors $r=0,723$. The herbicide level of herbicide has decreased from $100 \%$ to $35 \%$, with a correlation coefficient $r=0.888$, in plants Amaranthus retroflexus $L$. to increase epicutecular wax accumulation from $0.09 \mathrm{~g} / \mathrm{m}^{2}$ to $0.72 \mathrm{~g} / \mathrm{m}^{2}$.

In the level of effectiveness of the herbicide decreased from $100 \%$ to $35 \%$, the correlation coefficient $r$ $=0,886$.

Any organism in the process of life is inextricably linked with the environment in which it is located. In the process of interconnections there is an exchange of energy and substances, it is in this exchange and undergo complex processes of ensuring the processes of life $[1,2,3]$. On the one hand, the exchange of an organism with the environment ensures its existence, and on the other hand, the excessive influence of certain factors can lead not only to inhibition but also to the complete cessation of the processes of life. That is, the processes of mutual exchange of energy and matter of the organism and the environment must be regulated. Such a requirement is valid for all forms of life, including for plants $[4,5]$. At the level of individual cells in tissues of different specializations, such regulatory function is performed by biological membranes that change the permeability for the respective substances. Modern science has today a holistic membrane theory of transfer and systems for regulating the level of permeability of cellular biological membranes. This branch of research is developing very rapidly $[6,7,8]$. At the same time, higher plants, especially the representatives of the Angiospermae field in the process of evolution and life on the land, have created the next level of regulation of the processes of energy and substances coming from the environment into a living, complex organism by forming specialized cover tissues: crust, exoderm, cortex, epidermis (epidermis). A layer of specialized tissues with an appropriate wall structure acts as a barrier to excessive or undesirable effects of the medium much more efficiently than the membranes of a single cell $[9,10,11]$.

It covers the tissues covered both above ground and underground parts of plants. For example, one year old sunflower - Helianthus annuus $L$., beetroot sugar - Beta vulgaris $L$. f. sacharifera, soft wheat - Triticum avestium L., Elitriga repens (L.) Pal. Beauv., Amaranthus retroflexus L., etc. On the surface of the epidermis, which covers the above-ground parts of herbaceous plants, there is a cuticle that does not have a cellular structure. On the outside of the cuticle from the cells of the epidermis, gradually emerging stems or plates of various forms of epicutical waxes. Such formations are sufficiently plastic and gradually merge together, forming a continuous layer of amorphous matter on the surface of the leaves $[12,13,14$, 15, 16, 17].

Epicutecular waxes are complex organic substances that have a lipidic chemical nature. In the process of forming protective systems against adverse environmental effects, the membrane of the epidermis cells (epidermal) is impregnated with a variety of plant waxes - the corn. The cube is formed from fatty acids having a low molecular weight. The amount of corn may be sufficiently large, up to $3.5 \%$ of the dry mass of leaves $[18,19]$. Compared to fats, vegetable waxes are more rich in the presence of 
carbon atoms $(\mathrm{C})$ up to $80-82 \%$ and hydrogen $(\mathrm{H})$ up to $13-14 \%$, but they contain less oxygen atoms $(\mathrm{O})$ up to $4-7 \%$ [20] . Epicutilus waxes by nature are a mixture of esters of higher fatty acids and aliphatic alcohols, stearins and terpene alcohols. In esters, chemical bonds are more stable and more difficult to hydrolyze compared with fats. The carbohydrate components of the wax mainly consist of $\mathrm{H}$-alcohols formed during decarboxylation of free fatty acids. Traditionally, they contain an odd number of carbon atoms: from $C 11$ to $C 33[21,22]$. Such an amorphous layer on the surface substantially enhances the protective functions of the covering tissues of plants. It is bad or not wetted by water, does not pass water vapor and gases. Due to the presence of a layer of epicutical waxes, the evaporation of water from the cell cytoplasm through the surface of the leaves is on average 100 times less than the volume of evaporation through the stomata $[23,24]$

The epicutecular wax layer well reflects part of the energy of the sun's rays again into space, especially the ultraviolet and infrared portions of the spectrum. For example, lucid leaves of brilliant Atriplex nitens Selk., Composite Lettuce - Lactuca serriola L. and others. Such an optical feature of the surface of the leaves helps to optimize the temperature in the tissues and allows the plants to less waste water on the processes of transpiration. The layer of epicutile waxes on plant leaves is an essential barrier to the penetration of active pesticide substances into living tissues and conducting systems. Particularly important is the layer of epicutical waxes in increasing the resistance of weeds to the action of herbicides in conditions of dry, solar, windy weather and elevated environmental temperatures $[25,26$, 27].

Therefore, the study of the dynamics of the formation of the protective layer of epicatetic waxes on the surface of the aboveground parts of the weeds and ways to overcome them is an issue of relevance. The purpose of the micro-site and laboratory studies carried out in 2014-2018 was to clarify the peculiarities of the dynamics of the formation of the layer of epicutile waxes on the leaves of different types of weeds in the process of their organogenesis under different vegetation conditions of plants and determining the role of such a layer in the application of herbicides.

Methodology and conditions of research. The research was conducted in laboratories of IBCSB and IPP NAAS. Microparticular experiments involved sequential sowing of weed seeds into plots at different intervals at intervals of 6 days. Such a system of non-identical dates of the beginning of the vegetation provided differential treatment of stairs and, consequently, different levels of development of weed plants of the same species until the sampling time for the analysis and spraying with herbicides. Sowing area of a micro area - one meter square. Accounting area $0,5 \mathrm{~m}^{2}$. The repetition of experiments is -7 times. At the site, we left about 50 pieces $/ \mathrm{m}^{2}$ of one type of weed. The scheme of experiments envisaged:

1. Weed plants vegetate on areas without protective measures.

2. Weed plants vegetate to the formation of cotyledons. After sampling samples for analysis, they are sprayed with herbicides.

3. Weed plants vegetate to the formation of two leaves. After sampling sheets for analysis, they are sprayed with herbicides.

4. Weed plants vegetate to the formation of 4 leaves. After sampling the sheets of analyzes, they are sprayed with herbicides.

5. Weed plants vegetate to the formation of 6 leaves. After sampling sheets for analysis, they are sprayed with herbicides.

6. Weed plants vegetate to the formation of 8 leaves. After sampling sheets for analysis, they are sprayed with herbicides.

In parallel, all experimental variants were laid in both open soil and vegetation under a polymeric transparent film (protected soil), where the vegetation conditions of the plants were more stable. Under the film, the relative humidity of the air was traditionally $70-90 \%$. Under conditions of open soil, relative humidity fluctuated depending on weather conditions. The purpose of such parallel laying of options was to determine the effect of daily fluctuations in temperature and changes in the relative humidity of air on the intensity of the formation of the layer of epicutical waxes on the surface of the above-ground parts of 
plants, primarily on the leaves, on the level of effectiveness of herbicide action on such weeds. The areas selected for the analysis of leaves were determined by the method of "broaching" (according to AA Nichiporovich). To determine the number of epicutileous waxes on the leaves, the method of "washing" was used. After determining the area of 10 leaves of each species of weed plants, they were immersed in pre-weighed dry tubes for one hour in ether. After dissolution of the epicutical waxes from the leaf surface in the solvent, the leaf blanks were removed and the ether from the samples was evaporated in the extractor cabinet at a temperature of $20^{\circ} \mathrm{C}$.

Dissolved epicutilus waxes after complete evaporation of the ether remained on the walls of the tubes. The test tubes were weighed again. The difference in the weight of the samples was the mass of epicutile waxes washed away from the leaves formed during the stages of development of plants of a particular species under the corresponding vegetation conditions. The resulting mass of epicutile waxes was counted on the surface area of the used leaves in the sample (on both sides). Such a method for determining the presence of epicutical waxes on the leaves does not allow determining the magnitude of the accumulation of the protective layer on each side of the leaf blades, but gives a generalized index on both sides, both adaxial and abaca. After sampling the leaves of the plants for analysis, the sprays were sprayed with a manual sprayer with a working fluid with a herbicide. Betanal expert, e.c. (fenemidifami $91 \mathrm{~g} / \mathrm{l}$. + desmedifam $-71 \mathrm{~g} / \mathrm{l}$. + ethofumezate $110 \mathrm{~g} / \mathrm{l}$.) Normal consumption is $1.0 \mathrm{l} / \mathrm{ha}$. and the rate of consumption of the working fluid is $210 \mathrm{I}$. / ha.

To obtain an objective assessment of the level of effectiveness of the herbicide of the site with plants of different levels of development and accumulation of epicutical waxes on the surface of the leaves of microparticles sprayed simultaneously, under the same conditions of the same temperature, relative humidity of air, and other factors of weather. The application of herbicides, records and observations was carried out in accordance with the requirements of the Testing Method and the Use of Pesticides (edited by Prof. S. Treebel, 2001) [28].

Results and discussion. Weather conditions during the years of research were favorable for the growth and development of weed plants. Seed weed seeds at different times provided at the time of records and analyzes and spraying of juvenile plants in different phases of development. The intensity of the formation of the layer of protective epicotylic waxes on the leaves of weeds was influenced by both the phases of development of plants of different species and their morphological features and the variations of weather during the period of vegetation. Especially stimulates the formation of epicutical waxes, dry sunny and windy weather with high temperatures and low indicators of relative humidity. Such vegetation conditions contribute to the manifestation of xeromorphic features in young plants. In the first place, the formation of cells of the epidermis of smaller size on the surface of the leaf blades. Such a reaction may be explained by the need to increase the protection of stairs from excessive water loss during transpiration.

Epicutilus waxes perform a protective function from excessive transpiration and therefore the plants increase their layer on the surface of the leaf blades. All types of weeds that have been used in the studies have an overgrowth type of germination and with the help of hypocotyl, they carry cotyledons of seeds on the surface of the soil. Such cotyledons are the first parts of plants that begin to carry out photosynthesis processes and promote the transition of a young plant to autotrophic nutrition through photosynthesis. The analyzes conducted prove that on the surface of the green cotyledons of different types of weeds that were used in experiments, epicutilus waxes are almost absent. That is, such aboveground parts of the plants are not able to substantially protect and retain water in the cells of the aboveground tissues and do not constitute a significant barrier to the penetration of active substances of herbicides. During the formation of the first pair of true leaves (for the achievement of full growth and development of their leafy plates), the number of epicutilusal waxes on their surface was on average over the years of research: in plants of Chenopodium album L. - 0,16, in Polygonum scabrum L. - 0,21, in curry of the Amaranthus retroflexus $L$. $-0,23 \mathrm{~g} / \mathrm{m}^{2}$, respectively (Table). By the time of formation of the next pair of leaves (4 leaves in juvenile plants), the intensity of the formation of the layer of epicutical waxes increased. Their average amount in developed leaves was: in plants Chenopodium album L. - 
$0,24 \mathrm{~g} / \mathrm{m}^{2}$ or $50 \%$ more than the previous records. In rough Polygonum scabrum $L .0,26 \mathrm{~g} / \mathrm{m}^{2}$ or by $24 \%$ more compared with the previous indicators, in the steps of Amaranthus retroflexus $L .-0,31 \mathrm{~g} / \mathrm{m}^{2}$ or $35 \%$ more than in the phase of 2 leaves. Table.

Dynamics of formation of epicutical waxes on leaves of weed plants $\left(\mathrm{g} / \mathrm{m}^{2}\right), 2014-2018$

\begin{tabular}{|c|c|c|c|c|c|}
\hline \multirow[b]{2}{*}{ Types of weeds } & \multicolumn{5}{|c|}{ Phases of development of plants (leaves): } \\
\hline & seedlings & 2 & 4 & 6 & 8 \\
\hline \multicolumn{6}{|c|}{ Open ground } \\
\hline Chenopodium album L. & 0,08 & 0,16 & 0,24 & 0,38 & 0,57 \\
\hline Polygonum scabrum L. & 0,11 & 0,21 & 0,26 & 0,40 & 0,61 \\
\hline Amaranthus retroflexus $L$. & 0,09 & 0,23 & 0,31 & 0,44 & 0,72 \\
\hline \multicolumn{6}{|c|}{ Closed ground (under the film) } \\
\hline Chenopodium album L. & 0,04 & 0,06 & 0,07 & 0,09 & 0,11 \\
\hline Polygonum scabrum L. & 0,05 & 0,07 & 0,08 & 0,09 & 0,12 \\
\hline Amaranthus retroflexus $L$. & 0,06 & 0,07 & 0,09 & 0,10 & 0,13 \\
\hline $\mathrm{Nir}_{0,05}$ & 0,01 & 0,03 & 0,03 & 0,05 & 0,09 \\
\hline
\end{tabular}

In the presence of 6 plants in young plants, the presence of epicatetic wax on the surface of their leafy plates increased. Waxes in the process of their accumulation acquired the qualities of an increasingly powerful protective barrier in the way of the evaporation of water and penetration into the tissue of active substances of herbicides. On the surface of the leafy plates (average indicators of the presence of the protective layer of epicutical waxes on both sides) in different species of plants were not the same. On the leaves of Chenopodium album $L$. on the leafy leaves was an average of $0.38 \mathrm{~g} / \mathrm{m}^{2}$, in Polygonum scabrum L. $-0.40 \mathrm{~g} / \mathrm{m}^{2}$ and in curry of the Amaranthus retroflexus L. -0 , seedlings $44 \mathrm{~g} / \mathrm{m}^{2}$, respectively (Fig.). By the onset of the period of formation of the 8-leaf accumulation of epicutilusal waxes on the leafy plates, it increased and reached on average over the years of research: in plants of Chenopodium album L.- $0,57 \mathrm{~g} / \mathrm{m}^{2}$, in Polygonum scabrum L. $-0,61 \mathrm{~g} / \mathrm{m}^{2}$, in curry of the Amaranthus retroflexus $L . .-0,72 \mathrm{~g} / \mathrm{m}^{2}$. The increase in the number of epicutileous waxes on the leaflets compared with their presence in the phase of the formation of the two true leaves was: in plants of Chenopodium album L., 7,1 times, in rough Polygonum scabrum L. - 5,6 times, in curry of the Amaranthus retroflexus $L$. at 8,0 times Fig.

Level of effectiveness of herbicides depending on the number of epicutical waxes and phases of development of plants The values set are not absolute, but only indicative. In other conditions, vegetation of plants of these types of changes can be significantly different. This opinion is also confirmed by the dynamics of the accumulation of epicutical waxes on the leaflets of weed plants, which simultaneously undergo vegetation in a stable and higher level of relative humidity and absence of wind action and significant temperature fluctuations.

Cultivation was carried out on experimental sites under protected soil conditions (under synthetic transparent film). At night the plants were protected from the effect of lowering the temperature, and during the light period of the day received appropriate watering and ventilation. 


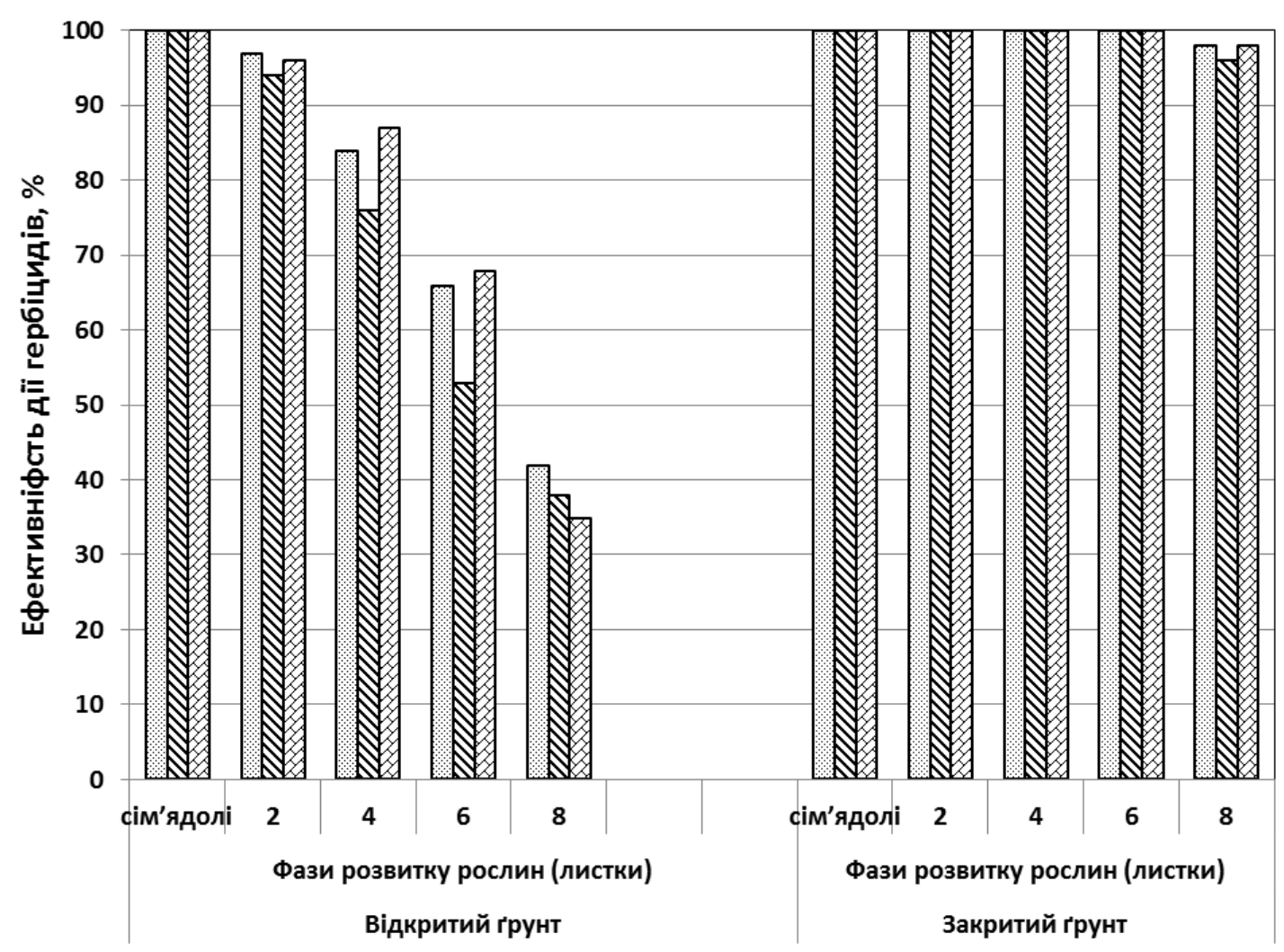

圆 Лобода біла 8 Гірчак шорсткий खщирия звичайна (загнута)

Open Ground

Closed Ground

Fig. Level of effectiveness of herbicides depending on the number of epicutical waxes and phases of development of plants

During the removal of the surface of the soil, the number of epicutical waxes on them was small. The analyzes revealed the presence of such substances, but their number amounted to an average of $0.04 \mathrm{~g} / \mathrm{m}^{2}$ in Chenopodium album $L$., to $0.06 \mathrm{~g} / \mathrm{m}^{2}$ in curds of the Amaranthus retroflexus $L$. In plants of Polygonum scabrum $L$. on the cotyledons, the presence of $0.05 \mathrm{~g} / \mathrm{m}^{2}$ was noted. In the period of the formation of two true leaves, the number of epicutile waxes in plants, which vegetate in the conditions of protected soil, grew very slowly. Compared to the vegetation accumulation in plants, the number of epicutical waxes was substantially lower in open ground: in plants of Chenopodium album $L$. it was 2.7 times, in rough gherkacha 3.0 times, in stew of Amaranthus retroflexus $L$. in 3,3 times. In the subsequent phases of plant development and the formation of leaves, the number of epicutileous waxes on the leafy plates gradually increased. However, at the time of the formation of the 8-leaf, their number was on average: Chenopodium album L. - 0,11, Polygonum scabrum L. - 0,12, Amaranthus retroflexus L. $\quad-0,13 \mathrm{~g} / \mathrm{m}^{2}$. Compared to plants that were vegetated in open soil under the influence of daily temperature fluctuations, dry wind, moisture deficit and direct sunlight, plants in the conditions of protected soil formed on the surface of leaves the layer of epicatetic waxes is significantly smaller. In plants, white lobos are in 5,2 times, in rough Polygonum scabrum L, 5,1 times, in common stew in 5,5 times. The number of epicutilusal waxes, which form on the surface of young plants, the protective layer has not only a purely academic but also an applied value. In the early stages of formation, the epucoticular waxes are amorphous (soft), but during the next period of exposure, under the influence of atmospheric factors and ultraviolet rays of sun, waxes undergo polymerization reactions, and they transform into the crystalline (solid) forms on the surface of the plant leaves. These forms of wax become 
more resistant to the effects of environmental factors, including the intensity of processes of physical diffusion of active substances of herbicides applied to their surface. After each sampling of the leaves for analysis in the appropriate phases of the formation of leaves of young weed plants, which were vegged both in the open ground and in the protected sprayed with a working fluid with a herbicide.

The average indicators of the level of effectiveness of the herbicide are shown in Figure 1.

The stairs of weeds vegged in open ground and during the spraying of herbicide formed a different number of leaves, showed the same sensitivity to the action of toxicants: the three active substances - fenmediphami, desmedifam, etofumezat. Plants of all types of weeds, which were used in experiments and formed only green cotyledons, died completely $(100 \%)$. In the phase of two leaves the level of extinction of young plants was on average from 94 to $97 \%$. In the presence of 4 leaves in weed plants, the sensitivity and degree of dying of stairs of various species decreased from 76 to $87 \%$. In the presence of uroliths of 8-leaf weeds, the effectiveness of the herbicide has decreased significantly and averaged 35 to $42 \%$.

In plants of each type of weed dynamics of resistance to active substances was its own, but the general trend of change was manifested very clearly. With the growth of the phases of the formation of leaves and the accumulation of a more powerful layer of epicutile waxes, weed stairs showed a phase resistance to the action of the herbicide. The direct connection between the number of epicutylaricules on the leafy plates of young weed plants and the level of sensitivity to the action of the herbicide is directly indicated by the results of the application of the same working fluid to the stairs that were vegged in a protected soil (under a synthetic film). In these stairs there was a different dynamics of accumulation of epicutical waxes and the level of effectiveness of the herbicide was different from that of vegetation plants in open soil.

The disappearance of weed hedges, which were previously vegetated under protected ground conditions, was almost complete, regardless of the number of leaves that the plants had for spraying. Only in the plants that formed the 8th leaf, the average dying rate was $96-98 \%$. The number of epicutilusal waxes on their leaves was close to the indices of plants, which vegetated in the open ground into the phase of formation of 2 leaves. As a result of the low level of protection of the leaf blades by the layer of epicutical waxes in vegetated plants in conditions of protected soil, active substances in the process of physical diffusion easily overcame such a protective barrier and penetrated the cytoplasm of living cells of chlorhenics and to the leading plant systems, and through them before action site Such a system of penetration provided a high level of effectiveness of herbicide on the stairs of weeds in different phases of growth and development. The correlation analysis of the results of the accumulation of the epicutical wax layer after the phases of development of the weeds species used in the experiments has been carried out, which proves that their vegetation under conditions of open and closed soil under the phases of development: cotyledons - 8th leaves, the correlation coefficient was Positive and in the plants of Chenopodium album L. $r=0.988$, in plants Polygonum scabrum L. $r=0,997$; Trigger of Amaranthus retroflexus $L$. $\quad r=0,990$. The level of effectiveness of the action of herbicides on the stairs of weeds by the phases of development and the different amount of accumulation of epicutical wax showed a negative correlation dependence. The coefficients of correlation showed high reliability. In plants, Chenopodium album L. $r=0.831$; Polygonum scabrum L. $r=0,723$; Trigger of Amaranthus retroflexus $L . \quad r=0,886$.

\section{Conclusions}

1. Epicutilus waxes, especially in the juvenile stage of organogenesis, are an effective protective means of young plants from undesirable environmental influences. Their protective layer on the surface can significantly increase, depending on the phases of development, the specific conditions of the environment and biological characteristics of plants of a particular species. The number of epicotilusal waxes in plants of Chenopodium album $L$. during growing in open soil increased from $0.08 \mathrm{~g} / \mathrm{m}^{2}$ (cotyledon) to $0.57 \mathrm{~g} / \mathrm{m}^{2}$ (8 th leaf), or at 7,1 times.

2. Vegetation of plants in conditions of protected soil, where the daily temperature fluctuations are significantly lower, and the relative humidity level is at least twice as much as the conditions of open soil, 
and in the absence of the effect of the wind, the formation of a layer of epicutile waxes on the surface of plants of Chenopodium album $L$. is 5.2 times smaller, $r=0.988$.

3. Epicutilus waxes are a significant obstacle to the diffusion of active substances of herbicides into tissue of mesophilic leaves. The growth of 5.6 times the amount of waxes on the leaves of rough Polygonum scabrum L. plants in the course of their development coincided with a decrease in the level of effectiveness of the herbicide on $62 \%$ Polygonum scabrum L., the correlation relationship was rather high, $r=0.783$. In herbs Amaranthus retroflexus $L$. to increase the accumulation of epicutical waxes from $0.09 \mathrm{~g} / \mathrm{m}^{2}$ to $0.72 \mathrm{~g} / \mathrm{m}^{2}$, the herbicide's effectiveness decreased from $100 \%$ to $35 \%$. The relationship of factors was $r=0,886$.

4. In the process of planning the spraying of crops with herbicides it is advisable to take into account the preliminary influence of environmental factors, which strengthen the processes of forming the layer of epicutile waxes on the leaves of weeds, especially the level of growth and development of plants, the need to add to the working fluid of penetrants, strengthening the processes of physical diffusion of active substances of preparations through protective covers of above-ground parts of plants of weeds.

\section{Literature:}

1. Vasilevich VI Types of plant strategies and photoconotypes. Journal of General Biology. - 1987. t. XLVIII. No. 3 -s. 368-374.

2. Ezau K. Anatomy of Seed Plants - Moscow: "The World" 1980. - Kn. 1. 2.

3. Clarkson D. Transport of ions and structure of the plant cell. -M .: "World" - 1978. -351s.

4. Shvartau V.V., Trach V.V. Physiological features of synergistic enhancement of the activity of derivatives of aryloxyphenoxypropionic acid with the help of inhibitors of lipid synthesis... Physiology and Biochemistry of Crop Plants. - 2000-32. №4. - with. 329-333.

5. Sokolov MS penetration into herbs of herbicides and some other exogenous substances. .. Agrochemicals. - 1970. — №4. - p.135-138.

6. Leninger A. Fundamentals of Biochemistry $-\mathrm{M}$.: "World" 1985 - 1056s. 7. Shulgin A.M. Agrometeorology and agro-climatology. — L .: Meteoizdat 1978. -196s.

8. Botvinovsky VV About Wetting the Epidermis of Leaves .. Reports of the ANSSR. - 1948. -Tom. XII-№3. -with. 581-584.

9. Protasov N.I. Some biological features of weed plants. .. Rational methods of plant protection against pests, diseases and weeds: Sat. scientific tr TSHF. Gorki, 1979: W.P. 59

10. Bnay W.G. Weed control programs: running and future trends. Aspects of applied biligy. 1993. 2: p.177-181.

11. Daly G.T. Leaf - surface wax in Poacolensor. Journal Exper. Bot. 1964. -15 43. - p. 160-165.

12. Juniper B.E. Growth development and the effect of the environment on the plant surfaces. Journal Linn. Soc. (London), 1960. - 56. 367p 413-420. 13.Claerchout S., Recheul D. \& De CB (2015) Sensitivity of Echinochloa crus-galli populations to bread herbicides: a comparison of betveen cropping systems. Weed Research 55, 470-481.

14. Kentschler J. Die Wasser bendenetzbarkait von Blatt ober flachen ihre submikroskopische Wachs struktur. Planta - 1971. 96. 2. -S.119-135.

15. Maartin E.T., Juniper B.E. The cuticulles of plants (Edward Arnild) (Publishers) IRB. — London, $1970-122 p$.

16. Mc Horter C. G., Paul R.N., Barrentine B.E., Morphology, Development and Recrystallization of Epicuticular Waxes of Sorghum halepense L., Weed Science. - 1999. - 38.1. - p. 23-33

17. Norris R.F., Buccovac N.J. Structure of the pear leaf cuticule with special reference to cuticular penetration. Amer Journal Bot. 1968.-55. 8. P. 975-983.

18. Nussbaum E.G., Wiese A.F., Crutchield D.E. The effects of temperature and rainfall on the emergence and growth of eight weeds. Weed Science, 1995. - 33. 2: - P. 165-170.

19. Radler F. B. The surface of the waxes of the sultana wine. Austr Journal Biol. - Science, 1965.18. 5. $-1045-1056$. 
20. Morderer E.Yu. Herbicides, mechanisms of action and application practice . E.Yu. Morderer, Yu.G. Merezhinsky, volume 1. -K .: Logos, 2009.-372p. 21. Rielofsen R.A. On the submicroscopic structure of the cuticular cell wax Acta bot. Necrl - 1952. - 1.1 - p. 90-114.

22. Sargent J.A. The penetrion of growth regulatirs into leaves Meded. Land biwhogeschool. V. 29. No. 3. 1994

23. Schaufele W.R. Einflusshoch wachsenden Unckautes (Chenopodium album L.) auf Entwiklung and Ertag der Zuckerrube. Zeitschrift fur Pflanzen krankheiten and Pflancenschitz. Journal of Plant Diseases and Protection Heft 93 (2). April 1996. Band 93. -S. 125-135.

24. Skid J.D. Structure and Composition of plant cuticle in relation to environmental factors and permibility. Bot Gaz - 1999.177.1. -55-72

25. Ozerova L.V., Shvartau V.V. Mechanisms of action of modern herbicides. Physiology and Biochemistry of Crop Plants. - 2005. - 37, №6. 468-494.

26. Shvartau V.V., Mikhals'kaya L. M. Herbicides Physico - chemical and biological properties. Kyiv: Logos. 2013. 906s.

27. Heap I.M. (2017) International survey of herbicide resistant weeds. Online Internet, December 30. Available at www. weeds science. com. Communication Open Access.

28. Trybel S.O. Method of testing and application of pesticides. Ed. prof. S.O. Tribel -K: World, -2001, $-447 \mathrm{~s}$. 